\title{
Review \\ The Progress of Global Antimicrobial Resistance Governance and Its Implication to China: A Review
}

\author{
Jia Yin ${ }^{1,2,+}$, Yu Wang ${ }^{3, \dagger}$, Xueran Xu ${ }^{1,2}$, Yinqi Liu ${ }^{1,2}$, Lu Yao ${ }^{1,2}$ and Qiang Sun ${ }^{1,2, *(1)}$ \\ 1 Center for Health Management and Policy Research, School of Public Health, Cheeloo College of Medicine, \\ Shandong University, 44 Wenhuaxi Rd, Jinan 250012, China; yinjia@sdu.edu.cn (J.Y.); \\ xuxueran1994@163.com (X.X.); liuyinqifendou@163.com (Y.L.); 18792140221@163.com (L.Y.) \\ 2 NHC Key Laboratory of Health Economics and Policy Research, Shandong University, 44 Wenhuaxi Rd, \\ Jinan 250012, China \\ 3 Department of Global Health, School of Public Health, Peking University, 38 Xueyuan Road, \\ Beijing 100191, China; ywang@bjmu.edu.cn \\ * Correspondence: qiangs@sdu.edu.cn; Tel.: +86-531-8838-2376 \\ + Co-first author.
}

Citation: Yin, J.; Wang, Y.; Xu, X.; Liu, Y.; Yao, L.; Sun, Q. The Progress of Global Antimicrobial Resistance Governance and Its Implication to China: A Review. Antibiotics 2021, 10, 1356. https://doi.org/10.3390/ antibiotics 10111356

Academic Editor:

David Rodríguez-Lázaro

Received: 28 September 2021

Accepted: 5 November 2021

Published: 6 November 2021

Publisher's Note: MDPI stays neutral with regard to jurisdictional claims in published maps and institutional affiliations.

Copyright: (c) 2021 by the authors. Licensee MDPI, Basel, Switzerland. This article is an open access article distributed under the terms and conditions of the Creative Commons Attribution (CC BY) license (https:// creativecommons.org/licenses/by/ $4.0 /)$.

\begin{abstract}
China has great potential for engaging in global actions on antimicrobial resistance (AMR) control. This study aims to summarize the process of global AMR governance and provide relevant policy recommendations on how China could take more initiative in the global AMR governance. We searched for academic articles and official document published or issued before December 2020 in e-journal databases, official websites of major organizations, and the relevant national ministries. This review revealed that global action on AMR control has experienced three stages: (1) The beginning stage (1980s and 1990s) when actions were mainly sponsored by high-income countries and AMR surveillance was focused on hospitals; (2) The rapid development stage (2000-2010) when global AMR governance began to concentrate on joint actions in multi-sectors, and developing countries were gradually involved in global actions; (3) The comprehensive stage (2011 to present) when global actions on AMR have covered various fields in different countries. China's AMR governance has fallen behind at the beginning but recently began to catch up with the global trend. The central government should take a far-fetched view, act decisively and positively towards the global efforts of addressing AMR to play a more active and greater role on the international stage.
\end{abstract}

Keywords: antimicrobial; resistance; global governance; China

\section{Background}

The decrease of mortality caused by infectious diseases has been considered to be partly due to the development of antibiotics. Thus, they are commonly used-and even overused-to prevent and treat bacterial infections in humans and animals. In recent years, the inappropriate use of antibiotics in hospitals has been reported in many low- and middle-income countries (LMICs) [1-3]. Moreover, the general public could easily access antibiotics in private pharmacies without prescription in these countries [4,5]. Globally, the consumption of antibiotics is expected to rise by $67 \%$ between 2010 and 2030 [6]. The excessive and inappropriate use of antibiotics has contributed to the surge of antimicrobial resistance (AMR). The World Bank reported that AMR would be the leading threat to human health in the next 30 years [7].

The phenomenon of AMR comprises the resistance of bacteria to medicines used to prevent and treat bacterial infections. These drug-resistant strains may infect humans and animals, causing persistent infections that are more difficult to treat than infections by non-resistant bacteria, resulting in prolonged disease duration, increased mortality, and added treatment costs [8]. For example, the duration of drug-resistant tuberculosis (TB) and the associated treatment cost can reach 3-4 times and 100-fold of that of drugsusceptible TB, respectively $[9,10]$. As AMR has extremely serious impacts on human 
health, and environmental and socio-economic development, it has become one of the core issues of global health development and health security. According to the World Bank's estimates, if the problem of AMR could not be effectively addressed, 10 million people would die of it annually by 2050, the annual GDP would be reduced by $3.8 \%$ in areas with high resistance rates, and husbandry production would be decreased by $2.6-7.5 \%[7,11]$. Traditional health issues such as maternal and child health, as well as the prevention of infectious diseases could be well-controlled by the efforts of the health sector. According to the framework of "One Health", a multi-faceted global strategy of cross-sectoral collaboration and communication to secure the health of humans, animals, and the environment, addressing AMR requires action across all levels of society [12]. In recent years, international organizations, including the United Nations (UN), the World Health Organization (WHO), and political forums such as the Group 20 (G20) and the Group 7 (G7), governments and various civil societies have actively developed policies and implemented actions to promote global AMR governance based on the "One Health" approach.

China is one of the largest producers and consumers of antibiotics in the world. In 2013 , a total of 162,000 tons of antibiotics were used in healthcare and agriculture in the country [13]. Examples of seriously irrational antibiotic use in humans and animals were commonly reported, and the detection rates of certain resistant bacteria have increased year by year $[13,14]$. As a country with the world's largest population and a significant role in global health, China has received high expectations from international communities in global health management, including addressing AMR. However, compared with the international level of AMR governance, there is a significant lag in the initiation and progress of AMR governance in China and its participation in global AMR governance, such as contributing to policy making, attending important international meetings, and providing experts for the global AMR workgroup.

We conducted this review at the macro-policy level with the aim of summarizing the major steps on combating AMR taken by the international community and China, comparing the progress of AMR governance between the two, providing relevant policy recommendations on how China could take more initiative in the global activities on AMR governance. We searched for academic articles, reports, official documents regarding AMR governance published or issued before December 2020 at the major periodical databases of PubMed, ISI Web of Science, Medline, and official websites of global organizations as well as relevant national ministries and commissions of China. Global and national activities and strategies on AMR governance were collected.

\section{History of AMR}

Since the discovery of penicillin in 1928, new antibiotics were continuously identified and developed. During the 1950s and 1960s, a variety of antibiotics were described, such as erythromycin, vancomycin, methicillin, and gentamicin [15-18]. In the early 1970s, a total of 52 new antibiotics were developed in five years [19]. These antibiotics had a wide range of applications in both the clinic and animal husbandry. However, hardly any antibiotic with a new chemical structure has appeared on the market since 1984 [20]. In parallel, the problem of AMR gradually became more and more aggravated. Penicillin-resistant Staphylococcus infections that first occurred in hospitals were increasingly prevalent in the early 1950s [21,22], and multidrug-resistant Staphylococcus aureus has become the main cause of nosocomial infections since the 1980s [23-25]. Antibiotic resistant strains spread rapidly around the world with the rapid development of global migration and cross-border trade. A newly discovered resistant strain in Europe would spread to the United States (U.S.) in the course of a few months [26]. Scientists realized that the problem of AMR could no longer be solved by discovering more antibiotics, and began to discuss about tackling AMR on a global scale. Since then, international activities on AMR governance have begun. 


\section{Progress of AMR Governance}

By reviewing of the global strategies and actions, we divided the progress of global AMR governance into three major stages.

\subsection{Stage I: The Initiating Stage}

The first stage, also called "the initiating stage", occurred between 1980s and 1990s. Led by the UN and WHO, the activities of combating AMR began to be implemented globally in the early 1980s. In November 1981, the global assembly on AMR governance held by the WHO Antimicrobial Resistance Working Group marked the beginning of global actions against AMR [27]. In 1989, the WHO developed the WHONET software to surveil AMR [28]. By 1996, 160 microbiology laboratories from 31 countries including China had installed this software [29]. In the 1990s, high-income countries (HLCs) like the U.S. and certain European states established their national AMR monitoring systems [30,31]. At this stage, global actions focused on the surveillance of clinical bacterial resistance and were mainly led by HLCs. However, surveillance was often implemented in hospitals without considering AMR in the community [32]. In this stage, few articles regarding actions on AMR control in the low-and middle-income countries (LMICs) were published.

During the same period, China was initiating reform and opening up to globalization. Various fields started to rapidly develop and the country began to correspond with international standards. In the 1980s, the first law on the administration of medicines for human use was formulated and announced by the national legislature [33]. In the 1990s, China was amongst countries affected by nosocomial infections in hospitals. The Ministry of Health (MoH) announced a regulatory guideline, in which the rational use of antibiotics was included as one of the measures to control nosocomial infections [34]. After the mid-1990s, a series of policies were issued by the Ministry of Agriculture (MoA) to control the use and residue of veterinary drugs [35-37]. However, there was no specific strategy or action on AMR governance at this stage, and few articles related to AMR in China were published in international journals (Table 1).

Table 1. Policy and regulation milestones on AMR control in China at stage I.

\begin{tabular}{|c|c|c|c|}
\hline Year & Policy & Issuer & Highlights \\
\hline 1984 & $\begin{array}{l}\text { China Pharmaceutical } \\
\text { Administration Act }\end{array}$ & $\begin{array}{l}\text { The Central Committee of the } \\
\text { Communist Party of China }\end{array}$ & $\begin{array}{l}\text { A national law on pharmaceutical } \\
\text { producing, selling, management in } \\
\text { hospitals, price, advertising, reserving, } \\
\text { supplying and surveillance. }\end{array}$ \\
\hline 1987 & $\begin{array}{l}\text { Regulations on Veterinary Drug } \\
\text { Administration }\end{array}$ & The State Council & $\begin{array}{c}\text { Regulations on the producing, selling, } \\
\text { management in veterinary hospitals, } \\
\text { advertising, reserving, supplying and } \\
\text { surveillance. }\end{array}$ \\
\hline 1994 & $\begin{array}{c}\text { Regulatory Guideline for } \\
\text { Nosocomial Infection Control } \\
\text { (Trial) }\end{array}$ & $\mathrm{MoH}$ & $\begin{array}{l}\text { This guideline contains regulations on } \\
\text { responsibilities of health administrations } \\
\text { and hospitals, infection surveillance, and } \\
\text { measures of infection control. }\end{array}$ \\
\hline 1994 & $\begin{array}{l}\text { Maximum Residue Limits for } \\
\text { Veterinary drug in Animal Foods } \\
\text { (Trial) (updated in 1999) }\end{array}$ & MoA & $\begin{array}{l}\text { The MoA defined the Maximum Residue } \\
\text { Limits for different kinds of poultry and } \\
\text { livestock. }\end{array}$ \\
\hline 1997 & $\begin{array}{c}\text { Regulations on types and usage of } \\
\text { veterinary drugs used as feed } \\
\text { additives }\end{array}$ & MoA & $\begin{array}{l}\text { Regulations on types, usage and dosage } \\
\text { for veterinary drugs. }\end{array}$ \\
\hline 1999 & $\begin{array}{l}\text { National action plan for } \\
\text { surveillance of residues in Animal } \\
\text { and Animal Food and official } \\
\text { sampling procedure }\end{array}$ & MoA & $\begin{array}{l}\text { This document specified the Laws and } \\
\text { regulations on surveillance of residues, } \\
\text { responsibilities of the supervisory } \\
\text { authorities, sampling procedure, etc. }\end{array}$ \\
\hline
\end{tabular}




\subsection{Stage II: The Stage of Rapid Development}

The rapid development stage took place from 2000 to 2010. In this stage, the consumption of antibiotics increased dramatically in LMICs [38]. Drug resistance was escalating worldwide, and the emergence of multidrug resistant strains and superbacteria raised the global alarm. In this context, international organizations and the HLCs began to be concerned about antibiotic use in agriculture and the environment, as well as AMR in LMICs. Global strategies implemented to fight AMR changed from monitoring to co-governance by several disciplines. This stage is marked by the issue of the WHO Global Strategy for Containment of Antimicrobial Resistance in 2001, which provided an interventional framework to reduce AMR from eight important aspects [39]. The WHO, FAO, and OIE carried out either independent or joint actions to combat global AMR. In 2005, the WHO published the first version of critically important antimicrobial agents for human medicine through discussions with the FAO and OIE [40].

At this stage, China accelerated the pace of integration into the international economic society due to joining the World Trade Organization in 2001. Domestic measures against AMR in the medical and agricultural fields began during this period. The first official document on improving the rational use of antibiotics was issued by the national Medical Products Administration in 2003, which limited the activities of selling antimicrobials without prescription in retail pharmacies [41]. During 2004 and 2008, a series of guidance documents were announced by $\mathrm{MoH}$, which aimed to standardize the clinical use of antibiotics and to control nosocomial infections caused by drug-resistant bacteria [42-45]. In 2005, two nationwide surveillance systems, namely, the "surveillance network for the use of antibiotics in healthcare institutions" and "China AMR surveillance system", were established by the government [46]. In 2009, a national AMR surveillance program was also implemented in agriculture field [47]. In the environmental field, the only action was a nationwide inspection of hazardous wastes including antibiotic residue [48]. However, these initiatives still mainly concentrated on the clinical monitoring of AMR and the promotion of rational antibiotics use (Table 2).

Table 2. Policy and regulation milestones on AMR control in China at stage II.

\begin{tabular}{|c|c|c|c|}
\hline Year & Policy & Issuer & Key Point \\
\hline 2003 & $\begin{array}{l}\text { A notice on strengthening the } \\
\text { supervision of antimicrobials } \\
\text { sales in retail pharmacies and } \\
\text { promoting rational use of } \\
\text { antibiotics }\end{array}$ & FDA & $\begin{array}{c}\text { In the retail pharmacies, the antimicrobials which } \\
\text { are Rx should be purchased with prescriptions from } \\
\text { a licensed physician. }\end{array}$ \\
\hline 2004 & $\begin{array}{l}\text { A guideline on clinical use of } \\
\text { antimicrobials } 42\end{array}$ & $\mathrm{MoH}$ & $\begin{array}{l}\text { To promote the rational use of antimicrobials and } \\
\text { regulate the behavior of medical healthcare facilities } \\
\text { and health care workers. }\end{array}$ \\
\hline 2005 & $\begin{array}{c}\text { A notice on the establishment of } \\
\text { clinical use of antimicrobials and } \\
\text { bacterial resistance monitoring } \\
\text { network }\end{array}$ & $\mathrm{MoH}$ & $\begin{array}{l}\text { The national monitoring networks of clinical use of } \\
\text { antimicrobials and bacterial resistance will be } \\
\text { established. }\end{array}$ \\
\hline 2006 & $\begin{array}{l}\text { Prescription Administrative } \\
\text { Policy } 43\end{array}$ & $\mathrm{MoH}$ & $\begin{array}{l}\text { The aims of this policy are to standardize } \\
\text { prescription management, improve the quality of } \\
\text { prescription, promote rational use of medicines, and } \\
\text { to ensure medical safety. }\end{array}$ \\
\hline 2008 & $\begin{array}{l}\text { A notice on strengthening the } \\
\text { control of nosocomial infection } \\
\text { causing by multi-drug resistant } \\
\text { bacteria44 }\end{array}$ & $\mathrm{MoH}$ & $\begin{array}{c}\text { This notice requires the hospitals to prevent and } \\
\text { control of nosocomial infection and to prevent and } \\
\text { control of nosocomial transmission of drug-resistant } \\
\text { bacteria. }\end{array}$ \\
\hline 2008 & $\begin{array}{l}\text { A notice on further improving the } \\
\text { clinical use of antimicrobials } 45\end{array}$ & $\mathrm{MoH}$ & $\begin{array}{l}\text { Further strengthening the preventive use of } \\
\text { antimicrobials in peripheral surgery and gradually } \\
\text { establishing an early warning mechanism for the } \\
\text { clinical use of antimicrobials. }\end{array}$ \\
\hline
\end{tabular}


Table 2. Cont.

\begin{tabular}{cccc}
\hline Year & Policy & Issuer & Key Point \\
\hline 2009 & $\begin{array}{c}\text { Animal Bacterial Resistance } \\
\text { Surveillance Program (2009)47 }\end{array}$ & MoA & $\begin{array}{c}\text { Strengthening the monitoring of animal-derived } \\
\text { bacterial resistance, ensuring the safety of } \\
\text { animal-derived food and promoting the healthy } \\
\text { development of animal husbandry. }\end{array}$ \\
$\begin{array}{c}\text { A notice on implementing special } \\
\text { inspection on the generation and } \\
\text { disposal of hazardous waste such } \\
\text { as antibiotic residue48 }\end{array}$ & MEP & $\begin{array}{c}\text { To organize nationwide inspection on the generation } \\
\text { and disposal of hazardous waste such as antibiotic } \\
\text { bacteria residue. }\end{array}$ \\
\hline
\end{tabular}

MoH: Ministry of Health (former name of National Health Commission); MoA: Ministry of Agriculture; MEP: Ministry of Ecology and Environment; NHFPC: National Health and Family Planning Commission (former name of National Health Commission).

\subsection{Stage III: The Comprehensive Stage}

During this stage, which covers the period of 2011 to the writing of this review, the high-level meeting of the UN General Assembly and political forum summits raised the importance of AMR from simply a threat to human health to a severe challenge of economic and social development. To attract more global attention to AMR, NGOs and similar organizations began to undertake activities, such as holding sessions, publishing reports, and supporting programs $[49,50]$. In 2015, the WHO, FAO, and OIE jointly launched an important strategy - the Global Action Plan for Antimicrobial Resistance — based on the "One Health" approach [51]. The plan integrates medical, husbandry, agricultural, environmental, and financial sectors into cooperation, and sets joint targets against AMR across all sectors. In the same year, the WHO established the Global Antimicrobial Resistance Surveillance System (GLASS), which aims to standardize the surveillance of AMR through a global collaborative effort [51].

China has also begun to strengthen its governance against AMR since 2011. From 2011 to 2013, three-year special activities on reducing antibiotic use in secondary and tertiary hospitals were implemented across the country [52-54]. In 2012, the national government issued a fierce regulation on the clinical use of antibiotics, which classified antibiotics into non-restricted, restricted, and special antibiotics based on their effectiveness, safety, bacterial resistance, and cost [55]. Only physicians with senior professional titles could prescribe all antibiotics, while junior physicians were only allowed to prescribe nonrestricted ones. In 2016, 14 national ministries jointly issued the National Action Plan for the Prevention of Bacterial Resistance 2016-2020 [56]. China became one of the first countries to develop their own National Action Plan (NAP). Based on the NAP, more actions were taken on improving the application of antibiotics for both human and animal use. In the clinical practice, the level of attention paid to antibiotic use and bacterial resistance in children was raised $[57,58]$. In the agricultural field, lomefloxacin, olaquindox, and six other antibiotics that could be formerly used for both humans and animals were banned in food animals between 2015 and 2017 [59]. Colistin sulfate has been banned from growth promotion in animals since April 2017 [60]. In 2018, 2019, and 2021, the MoA issued a surveillance plan for each antibiotic resistant zoonotic bacteria to ensure the safety of animal source foods [61-63]. However, few policies or actions were proposed in the environmental field. The only policies on reducing antibiotic residues and AMR pathogens in the environment were proposed and suggested for development by the deputies in the National People's congresses held in 2015 and 2017. China also initiated international cooperation projects through the formulation of NAP, and initially participated in global actions against AMR in this period (Table 3). 
Table 3. Policy and regulation milestones on AMR control in China at stage III.

\begin{tabular}{|c|c|c|c|}
\hline Year & Policy & Issuer & Key Point \\
\hline 2011-2013 & $\begin{array}{l}\text { Implementation Plan for Special } \\
\text { Rectification on Nationwide } \\
\text { Clinical Antibiotic Use } \\
(2011,2012,2013)\end{array}$ & NHFPC & $\begin{array}{l}\text { From } 2011 \text { to } 2013 \text {, special activity plans } \\
\text { on governance antibiotic use were issued } \\
\text { every year, focusing reducing antibiotic } \\
\text { use in secondary and tertiary hospitals. } \\
\text { This regulation specified the }\end{array}$ \\
\hline 2012 & $\begin{array}{l}\text { Regulations of administrative } \\
\text { measures for clinical application } \\
\text { of antibacterial agents }\end{array}$ & $\mathrm{MoH}$ & $\begin{array}{l}\text { responsibilities and legal responsibility of } \\
\text { health care institutions, health care } \\
\text { workers and health administrative } \\
\text { departments on management of clinical } \\
\text { application of antibacterial agents. }\end{array}$ \\
\hline 2015 & $\begin{array}{c}\text { National five-year action plan on } \\
\text { comprehensive management of } \\
\text { veterinary drugs (antimicrobials) } \\
\text { (2015-2019) }\end{array}$ & MoA & $\begin{array}{c}\text { five-year targets of zero use of veterinary } \\
\text { drug prohibited, }>97 \% \text { qualified rate of } \\
\text { veterinary antimicrobials, }>97 \% \text { qualified } \\
\text { rate of surveillance on residue of } \\
\text { veterinary drugs. }\end{array}$ \\
\hline 2016 & $\begin{array}{l}\text { National Action Plan on } \\
\text { antimicrobial resistance } \\
\text { (2016-2020) }\end{array}$ & NHFPC & $\begin{array}{l}\text { To implement comprehensive } \\
\text { management strategies at the national } \\
\text { level, and strengthen publicity and } \\
\text { education and international exchanges } \\
\text { and cooperation. }\end{array}$ \\
\hline 2017 & $\begin{array}{l}\text { National action Plan on rational } \\
\text { use of antibacterial in children } \\
\text { (2017-2020) }\end{array}$ & NHFPC & $\begin{array}{l}\text { Regulations on clinical use of } \\
\text { antibacterial in children, surveillance of } \\
\text { antimicrobial resistance, public education, } \\
\text { and training of healthcare workers. }\end{array}$ \\
\hline 2017 & $\begin{array}{l}\text { A notice on further strengthening } \\
\text { the clinical use of antibacterial } \\
\text { and curbing bacterial resistance }\end{array}$ & NHFPC & $\begin{array}{l}\text { To propose some requirements for weak } \\
\text { links in the clinical use of antimicrobials }\end{array}$ \\
\hline 2018 & $\begin{array}{l}\text { A notice on continuous improving } \\
\text { clinical use of antibacterial }\end{array}$ & $\mathrm{NHC}$ & $\begin{array}{l}\text { To accelerate the construction of } \\
\text { multidisciplinary teams of antibacterial } \\
\text { management, diagnosis and treatment, } \\
\text { strengthen the clinical use of } \\
\text { antimicrobials in vulnerable populations, } \\
\text { such as children. }\end{array}$ \\
\hline 2018-2021 & $\begin{array}{l}\text { Surveillance Plan for Antibiotic } \\
\text { resistant zoonotic bacteria } \\
\quad(2018,2019,2021)\end{array}$ & $\mathrm{MoA}$ & $\begin{array}{l}\text { To strengthen the monitoring of antibiotic } \\
\text { resistance in animal sources, promote the } \\
\text { rational use of medicines, and ensure the } \\
\text { safety of animal source foods. }\end{array}$ \\
\hline 2020 & $\begin{array}{l}\text { A notice on improving } \\
\text { surveillance on clinical use of } \\
\text { antibacterial and bacterial } \\
\text { resistance in children }\end{array}$ & $\mathrm{NHC}$ & $\begin{array}{c}\text { A total of } 67 \text { Children's hospitals or } \\
\text { Maternal and Child Health Hospitals } \\
\text { across the country were selected as the } \\
\text { surveillance sites. }\end{array}$ \\
\hline
\end{tabular}

MoA: Ministry of Agriculture; NHFPC: National Health and Family Planning Commission (former name of National Health Commission); NHC: National Health Commission.

\section{Effectiveness of AMR Governance}

After nearly four decades of governance, the global has made some achievements in combating AMR. Compared to 2010, 12 and 8 countries of the 40 countries that provided data reported lower volume of human- and animal-use antibiotic consumption in 2020, with most of them were HICs [64]. During 2006 and 2014, the incidence rates of Methicillinresistant Staphylococcus aureus (MARS) reduced by 18\%, 44\%, and 16\% in Europe, the U.S. and Canada, respectively [65]. However, the overall demand for antibiotics and the total burden of AMR in the world, especially in the low-income areas, continues to rise. Globally, the consumption of human-use antibiotic increased by 65\% between 2000 and 2015, and the consumption of animal-use antibiotics is estimated to increase by $12 \%$ during 2017 and 2030 [66]. One-third of studies conducted in Asia identified more than 50\% antimicrobial compounds with resistance in aquaculture between 2000 and 2019 [67]. Resistance rates for 
most of the priority antibiotic-pathogens reported by WHO were higher in the LMICs than in the HICs [64].

China has also made some progress on controlling AMR in the last decade. The rate of prescribing antibiotics decreased from $19.4 \%$ in 2010 to $7.7 \%$ in 2017 for outpatients, and from $67.3 \%$ to $36.8 \%$ for inpatients in the surveillance hospitals; likewise, the identify rates of most of the concerning resistant pathogens, such as MRSA, carbapenem-resistant klebsiella pneumoniae, and third-generation cephalosporin-resistant Escherichia coli, etc. have declined [68]. However, similar as in other large countries, huge amounts of antibiotics were used in Chinese agriculture $[13,66]$, and the country has seen industrial livestock and poultry develop rapidly to feed a population of 1.4 billion. In 2020, China used an estimate of 43,024 tonnes of antibiotics for animals [64]. Although the government has issued policies to curb the non-therapeutic administration of more than 150 antimicrobial products to food-producing animals, antibiotics are still extensively applied for animal disease prevention and growth promotion in the last few years $[69,70]$.

\section{Implications to China}

\subsection{Advantages and Disadvantges of China to Contribute to Global AMR Governance}

As one of the largest antibiotic producers and consumers, in addition to domestic AMR governance, China could also make more contributions to the global AMR governance. Compared with the global actions on AMR control, China's actions are relatively lagging behind at each stage. However, China has taken more actions and begun to catch up with the international pace of AMR governance in recent years. The government has realized the importance of AMR governance. In some important international conferences such as the Hangzhou summit, Chinese health authorities expressed their willingness to contribute to global governance initiatives against AMR. China has a great capacity to contribute to global AMR governance. The Chinese healthcare system, led by the National Health Commission with a top-down management approach, has the advantage of rallying resources on effective governance actions, and has gained important successes. China is one of the countries has the highest burden of TB in the word. In 1990s, China implemented the DOTS strategy to control TB throughout the country. Then, along with international TB control projects, the central government provided technical, financial, and equipment resources to TB control institutions across the country [71,72]. With the support of DOTS, the TB prevalence rate dramatically declined, while the treatment success rates rapidly increased [73]. The successful experiences of China's TB control were subsequently recommended by the $\mathrm{WHO}$ to the other high TB-burden countries. In recent decades, more and more Chinese researchers have been involved in studies on AMR and thus contributed to global AMR control. In 2013, a Chinese research team discovered mcr-1, a new and transmissible polymyxin-resistance gene [74]. Based on this finding, multiple countries and international organizations elevated the risk level of polymyxin.

Nonetheless, China still faces a number of challenges in both domestic AMR governance and the level of contribution to global AMR governance. At present, the departmental cooperation led by the Medical and Health Hospital of the National Health and Wellness Committee still solely focuses on the clinical monitoring of AMR. This business division mechanism has made China unable to fully carry out its duties necessary to address the resistance issue, such as public education and awareness, as well as drug research. The current expert committee on AMR lacks expertise in the fields of agriculture, environment and policy making. In addition, there are regional differences in AMR governance. The surveillance of antibiotic use in urban areas, as well as secondary and tertiary level healthcare institutions is efficient; however, it is less adequate in rural areas and primary healthcare institutions [75]. Moreover, China's data sharing with the international community is limited. By April 2020, a total of 92 countries, territories or areas have joint GLASS that is promoted by the WHO [76]. However, despite being one of the major antibiotics consumers, China has neither joined this system nor proposed plans for future participation, putting the country in a passive situation on the international platform of global AMR governance. 
There are governance policies in the agricultural sector, but these are still insufficient in terms of action and supervision. The environmental sector is also passive and remains on the stage of coordinating the medical and agricultural sectors.

\subsection{Implications to China to Contribute to Global AMR Governance}

There are several implications for China to contribute to global AMR governance. First, a management department whose rank is higher than ministries should be established by the State Council. Its main responsibilities would be to coordinate cooperation among ministries, organize a comprehensive expert committee, prepare monitoring plans and indicator systems of antibiotic use and drug-resistance in various fields, and represent China in international communications. Second, researches on AMR should be facilitated and cross-border cooperation studies should be further expanded. Civil societies and various partnerships, such as "the Belt and Road" initiative, the Shanghai Cooperation Organization, or the $16+1$ cooperation between Central and Eastern Europe could be utilized to support the global governance program of AMR. Third, more should be done to promote the disclosure of information; information transparency in the agricultural field should be enhanced. Work can be started by gradually sharing China's population resistance data with the international community. Forth, high-level comprehensive talents should be cultivated, such as using advanced training or secondment opportunities to nurture diplomatic talents in the health field, transforming professional knowledge into diplomatic language. Some global AMR governance experts have played roles in existing international organizations, and these roles should be fully supported. Finally, pharmaceutical innovation should be encouraged. Pharmaceutical companies should be encouraged to invest more in the research and development of new and alternative drugs. The advantages of Chinese traditional medicine should also be fully exploited.

\section{Limitations}

This study has several limitations in terms of data collection. First, we only searched relevant journal articles in three international periodical databases due to the time constraint. Second, this study focused on studies or policies at the macro level without including studies at the molecular level because there are multiple studies regarding AMR at the molecular level and they provided limited information for this topic. Third, few literatures or documents on environmental aspects were collected and analyzed, thus more studies focusing on AMR in this field are recommended. Finally, it would be necessary to collect interpretations from official points of view.

\section{Conclusions}

The global AMR governance has gradually progressed from focusing on clinical AMR surveillance to joint-actions against AMR across multiple sectors in the last forty years. China is catching up with the progress of international AMR governance, but the long-term strategies to tackle AMR in China are more concentrated on monitoring, especially in the agricultural and environmental fields. To contribute more to global AMR governance, the country should view it from the perspective of safeguarding public health, national health security, and the "One Health" principle, take a far-fetched view, and seize the opportunity to act decisively and positively toward the global efforts of addressing AMR, showing responsibility at an international level.

Author Contributions: J.Y. and Q.S. designed the study. J.Y., Y.W., X.X., Y.L., L.Y. and Q.S. collected the data. J.Y., X.X., Y.L. and L.Y. analyzed the data. J.Y. and Y.W. drafted the manuscript. Q.S. made critical revisions to the manuscript. All authors have read and agreed to the published version of the manuscript.

Funding: This study was supported by National Natural Science Foundation of China (grant number: 71774103) and China-UK Global Health Support Program funded by UK DFID (grant number: 202708). 
Institutional Review Board Statement: Not applicable.

Informed Consent Statement: Not applicable.

Conflicts of Interest: The authors declare that they have no competing interests.

\section{References}

1. Andrajati, R.; Tilaqza, A.; Supardi, S. Factors related to rational antibiotic prescriptions in community health centers in Depok City, Indonesia. J. Infect. Public Health 2017, 10, 41-48. [CrossRef]

2. Kotwani, A.; Holloway, K. Antibiotic prescribing practice for acute, uncomplicated respiratory tract infections in primary care settings in New Delhi, India. Trop. Med. Int. Health 2014, 19, 761-768. [CrossRef] [PubMed]

3. Wei, X.; Zhang, Z.; Walley, J.D.; Hicks, J.P.; Zeng, J.; Deng, S.; Zhou, Y.; Yin, J.; Newell, J.N.; Sun, Q.; et al. Effect of a training and educational intervention for physicians and caregivers on antibiotic prescribing for upper respiratory tract infections in children at primary care facilities in rural China: A cluster-randomised controlled trial. Lancet Glob. Health 2017, 5, e1258-e1267. [CrossRef]

4. Chang, J.; Xu, S.; Zhu, S.; Li, Z.; Yu, J.; Zhang, Y.; Zu, J.; Fang, Y.; Ross-Degnan, D. Assessment of non-prescription antibiotic dispensing at community pharmacies in China with simulated clients: A mixed cross-sectional and longitudinal study. Lancet Infect. Dis. 2019, 19, 1345-1354. [CrossRef]

5. $\quad$ Chuc, N.T.K.; Hoa, N.P.; Hoa, N.Q.; Nguyen, N.T.T.; Loan, H.T.; Toan, T.K.; Phuc, H.D.; Horby, P.; Van Yen, N.; Van Kinh, N.; et al. Antibiotic sales in rural and urban pharmacies in northern Vietnam: An observational study. BMC Pharmacol. Toxicol. 2014, 15, 6.

6. Van Boeckel, T.P.; Brower, C.; Gilbert, M.; Grenfell, B.T.; Levin, S.A.; Robinson, T.P.; Teillant, A.; Laxminarayan, R. Global trends in antimicrobial use in food animals. Proc. Natl. Acad. Sci. USA 2015, 112, 5649-5654. [CrossRef] [PubMed]

7. Bloom, G.; Merrett, G.B.; Wilkinson, A.; Lin, V.; Paulin, S. Antimicrobial resistance and universal health coverage. BMJ Glob. Health 2017, 2, e000518. [CrossRef]

8. Antimicrobial Resistance. World Health Organization. Available online: https://www.who.int/news-room/fact-sheets/detail/ antimicrobial-resistance (accessed on 31 July 2021).

9. Fitzpatrick, C.; Floyd, K. A systematic review of the cost and cost effectiveness of treatment for multidrug-resistant tuberculosis. Pharmacoeconomics 2012, 30, 63-80. [CrossRef]

10. Tanimura, T.; Jaramillo, E.; Weil, D.; Raviglione, M.; Lonnroth, K. Financial burden for tuberculosis patients in low- and middle-income countries: A systematic review. Eur. Respir. J. 2014, 43, 1763-1775. [CrossRef]

11. World Bank. Drug-Resistant Infections: A Threat to Our Economic Future. In License: Creative Commons Attribution CC BY 3.0 IGO; World Bank: Washington, DC, USA, 2017.

12. What is One Health. One Health Global. Available online: http://www.onehealthglobal.net/what-is-one-health/ (accessed on 2 July 2021).

13. Zhang, Q.Q.; Ying, G.G.; Pan, C.G.; Liu, Y.S.; Zhao, J. Comprehensive evaluation of antibiotics emission and fate in the river basins of China: Source analysis, multimedia modeling, and linkage to bacterial resistance. Env. Sci. Technol. 2015, 49, 6772-6782. [CrossRef]

14. Qiao, M.; Ying, G.G.; Singer, A.C.; Zhu, Y.G. Review of antibiotic resistance in China and its environment. Environ. Int. 2018, 110, 160-172. [CrossRef]

15. Brittain, D.C. Erythromycin. Med. Clin. North. Am. 1987, 71, 1147-1154. [CrossRef]

16. Griffith, R.S. Introduction to vancomycin. Rev. Infect. Dis. 1981, 3 (Suppl. S2), S200-S204. [CrossRef]

17. Sutherland, R.; Rolinson, G.N. Characteristics of methicillin-resistant staphylococci. J. Bacteriol. 1964, 87, 887-899. [CrossRef] [PubMed]

18. Weinstein, M.J.; Luedemann, G.M.; Oden, E.M.; Wagman, G.H. Everninomicin, a new antibiotic complex from micromonospora carbonacea. Antimicrob. Agents Chemother. 1964, 10, 24-32.

19. Su, X. The glory and challenges of antibiotics. Obs. Ponder. 2011, 22-23.

20. Elder, D.P.; Kuentz, M.; Holm, R. Antibiotic Resistance: The Need for a Global Strategy. J. Pharm. Sci. 2016, 105, 2278-2287. [CrossRef] [PubMed]

21. Serck-Hanssen, F. Penicillin-resistant staphylococci in a hospital's environment and in acute puerperal mastitis. Acta Chir. Scand. 1952, 104, 236-243.

22. Rountree, P.M.; Barbour, R.G. Incidence of penicillin-resistant and streptomycin-resistant staphylococci in a hospital. Lancet 1951, 1, 435-436. [CrossRef]

23. Price, E.H.; Brain, A.; Dickson, J.A. An outbreak of infection with a gentamicin and methicillin-resistant Staphylococcus aureus in a neonatal unit. J. Hosp. Infect. 1980, 1, 221-228. [CrossRef]

24. Rubin, L.G.; Medeiros, A.A.; Yolken, R.H.; Moxon, E.R. Ampicillin treatment failure of apparently beta-lactamase-negative Haemophilus influenzae type b meningitis due to novel beta-lactamase. Lancet 1981, 2, 1008-1010. [CrossRef]

25. Gragan, D.; King, K.; Brady, L.; Harkness, J. Gentamicin-resistant staphylococci. Lancet 1981, 2, 698-699.

26. Tiong, J.J.; Loo, J.S.; Mai, C.W. Global Antimicrobial Stewardship: A Closer Look at the Formidable Implementation Challenges. Front. Microbiol. 2016, 7, 1860. [CrossRef] [PubMed]

27. Group, W.H.O.S.W. Antimicrobial resistance. Bull. World Health Organ. 1983, 61, 383-394.

28. World Health Organization. The WHO Network on Antimicrobial Resistance Monitoring. Wkly. Epidemiol. Rec. 1996, $71,185-187$. 
29. Rahal, K.; Wang, F.; Schindler, J.; Rowe, B.; Cookson, B.; Huovinen, P.; Marton, A.; Lalitha, M.K.; Semina, N.; Kronvall, G.; et al. Reports on surveillance of antimicrobial resistance in individual countries. Clin. Infect. Dis. Off. Publ. Infect. Dis. Soc. Am. 1997, 24 (Suppl. S1), S169-S175. [CrossRef]

30. McDermott, P.F.; Zhao, S.; Wagner, D.D.; Simjee, S.; Walker, R.D.; White, D.G. The food safety perspective of antibiotic resistance. Anim. Biotechnol. 2002, 13, 71-84. [CrossRef]

31. Putman, L. Keeping global tabs on antimicrobial resistance. Lancet 1998, 351, 1264. [CrossRef]

32. Shlaes, D.M. Role of Antimicrobial Stewardship in Prevention and Control of Antibiotic Resistance. Curr. Infect. Dis. Rep. 1999, 1, 334-337. [CrossRef]

33. The Central Committee of the Communist Party of China. China Pharmaceutical Administration Act; The Central Committee of the Communist Party of China: Beijing, China, 1984.

34. Ministry of Health. Regulatory Guideline for Nosocomial Infection Control (Trial); MoH: Beijing, China, 1994.

35. Ministry of Agriculture. Maximum Residue Limits for Veterinary drug in Animal Foods (Trial); MoA: Beijing, China, 1994.

36. Ministry of Agriculture. Regulations on types and usage of veterinary drugs used as feed additives. Feed Res. 1997, 39-41.

37. Ministry of Agriculture. National action plan for surveillance of residues in Animal and Animal Food and official sampling procedure. Chin. J. Vet. Drug 2003, 37, 52-53.

38. Premanandh, J.; Samara, B.S.; Mazen, A.N. Race against Antimicrobial Resistance Requires Coordinated Action-An Overview. Front. Microbiol. 2015, 6, 1536. [CrossRef] [PubMed]

39. World Health Organization. WHO Global Strategy for Containment of Antimicrobial Resistance; WHO: Geneva, Switzerland, 2001.

40. World Health Organization. Critically Important Antibacterial Agents for Human Medicine for Risk Management Strategies of NonHuman Use; WHO: Canberra, Australia, 2001.

41. National Medical Products Administration. A Notice on Strengthening the Supervision of Antimicrobials Sales in Retail Pharmacies and Promoting Rational Use of Antibiotics; NMPA: Beijing, China, 2003.

42. Ministry of Health. A Guideline on Clinical Use of Antimicrobials; MoH: Beijing, China, 2004.

43. Ministry of Health. Prescription Administrative Policy; MoH: Beijing, China, 2006.

44. Ministry of Health. A Notice on Strengthening the Control of Nosocomial Infection Causing by Multidrug Resistant Bacteria; MoH: Beijing, China, 2008.

45. Ministry of Health. A Notice on Further Improving the Clinical Use of Antimicrobials; MoH: Beijing, China, 2008.

46. Ministry of Health. A Notice on the Establishment of Clinical Use of Antimicrobials and Bacterial Resistance Monitoring Network; MoH: Beijing, China, 2005.

47. Ministry of Agriculture. Animal Bacterial Resistance Surveillance Program (2009); MoA: Beijing, China, 2009.

48. Ministry of Ecology and Environment. A Notice on Implementing Special Inspection on the Generation and Disposal of Hazardous Waste such as Antibiotic Residue; MEP: Beijing, China, 2009.

49. Cars, O.; Hedin, A.; Heddini, A. The global need for effective antibiotics-moving towards concerted action. Drug Resist. Updates: Rev. Comment. Antimicrob. Anticancer Chemother 2011, 14, 68-69. [CrossRef]

50. Chaudhary, A.S. A review of global initiatives to fight antibiotic resistance and recent antibiotics discovery. Acta Pharm. Sin. B 2016, 6, 552-556. [CrossRef] [PubMed]

51. World Health Organization. Global Action Plan on Antimicrobial Resistance; WHO: Geneva, Switzerland, 2015.

52. Ministry of Health. Implementation Plan for Special Rectification on Nationwide Clinical Antibiotic Use (2011); MoH: Beijing, China, 2011.

53. Ministry of Health. Implementation Plan for Special Rectification on Nationwide Clinical Antibiotic Use (2012); MoH: Beijing, China, 2012.

54. Ministry of Health. Implementation Plan for Special Rectification on Nationwide Clinical Antibiotic Use (2013); MoH: Beijing, China, 2013.

55. Ministry of Health. Regulations of Administrative Measures for Clinical Application of Antibacterial Agents; MoH: Beijing, China, 2012.

56. National Health and Family Planning Commission; National Development and Reform Commission; Ministry of Education; Ministry of Science and Technology; Ministry of Industry and Information Technology; Ministry of Finance; Ministry of Land and Resources; Ministry of Environmental Protection; Ministry of Agriculture; Ministry of Culture; et al. National Action Plan for the Prevention of Bacterial Resistance 2016-2020; NHFPC: Beijing, China, 2016.

57. Children's National Medical Center. National action Plan on rational use of antibacterial in children (2017-2020). Chin. J. Pract. Pediatrics 2018, 33, 1-5.

58. National Health Commission. A Notice on Improving Surveillance on Clinical Use of Antibacterial and Bacterial Resistance in Children; NHC: Beijing, China, 2020.

59. Sha, L.; Tang, X.; Liu, D.; Xu, Y.; Ding, Y.U.; Ding, F. Detection and Quantitation of Lomefloxacin and Pefloxacin Residues in the Organ Tissues and Eggs of Laying Hens. J. Food Prot. 2018, 81, 810-814. [CrossRef]

60. Wang, Y.; Xu, C.; Zhang, R.; Chen, Y.; Shen, Y.; Hu, F.; Liu, D.; Lu, J.; Guo, Y.; Xia, X.; et al. Changes in colistin resistance and mcr-1 abundance in Escherichia coli of animal and human origins following the ban of colistin-positive additives in China: An epidemiological comparative study. Lancet Infect. Dis. 2020, 20, 1161-1171. [CrossRef]

61. Ministry of Agriculture. Surveillance Plan for Antibiotic Resistant Zoonotic Bacteria (2018); MoA: Beijing, China, 2018.

62. Ministry of Agriculture. Surveillance Plan for Antibiotic Resistant Zoonotic Bacteria (2019); MoA: Beijing, China, 2019. 
63. Ministry of Agriculture. Surveillance Plan for Antibiotic Resistant Zoonotic Bacteria (2021); MoA: Beijing, China, 2021.

64. Sriram, A.; Kalanxhi, E.; Kapoor, G.; Craig, J.; Balasubramanian, R.; Brar, S.; Criscuolo, N.; Hamilton, A.; Klein, E.; Tseng, K. State of the World's Antibiotics 2021: A Global Analysis of Antimicrobial Resistance and Its Drivers; The Center for Disease Dynamics, Economics \& Policy: Washington, DC, USA, 2021.

65. Center for Disease Dynamics, Economics \& Policy. State of the World's Antibiotics, 2015; CDDEP: Washington, DC, USA, 2015.

66. Klein, E.Y.; Van Boeckel, T.P.; Martinez, E.M.; Pant, S.; Gandra, S.; Levin, S.A.; Goossens, H.; Laxminarayan, R. Global increase and geographic convergence in antibiotic consumption between 2000 and 2015. Proc. Natl. Acad. Sci. USA 2018, 115, E3463-E3470. [CrossRef]

67. Schar, D.; Zhao, C.; Wang, Y.; Larsson, D.G.; Gilbert, M.; Van Boeckel, T.P. Twenty-year trends in antimicrobial resistance from aquaculture and fisheries in Asia. Nat. Commun. 2021, 12, 5384. [CrossRef]

68. National Health Community. China Antimicrobial Resistance Surveillance Report 2019; NHC: Beijing, China, 2019.

69. $\mathrm{Hu}, \mathrm{Y}$; C Cheng, H. Elevated antimicrobial residues in animal food products call for institutional changes on veterinary drug management and animal food product surveillance in China. Int. J. Antimicrob. Agents 2018, 51, 165-166. [CrossRef]

70. Wang, H.; Chu, Y.; Fang, C. Occurrence of Veterinary Antibiotics in Swine Manure from Large-scale Feedlots in Zhejiang Province, China. Bull. Environ. Contam. Toxicol. 2017, 98, 472-477. [CrossRef] [PubMed]

71. Xianyi, C.; Fengzeng, Z.; Hongjin, D.; Liya, W.; Lixia, W.; Xin, D.; Chin, D.P. The DOTS strategy in China: Results and lessons after 10 years. Bull. World Health Organ. 2002, 80, 430-436.

72. Tang, S.; Squire, S.B. What lessons can be drawn from tuberculosis (TB) control in China in the 1990s? An analysis from a health system perspective. Health Policy 2005, 72, 93-104. [CrossRef] [PubMed]

73. World Health Organization. Global Tuberculosis Report 2020; WHO: Genova, Switzerland, 2020.

74. Liu, Y.Y.; Wang, Y.; Walsh, T.R.; Yi, L.X.; Zhang, R.; Spencer, J.; Doi, Y.; Tian, G.; Dong, B.; Huang, X.; et al. Emergence of plasmid-mediated colistin resistance mechanism MCR-1 in animals and human beings in China: A microbiological and molecular biological study. Lancet Infect. Dis. 2016, 16, 161-168. [CrossRef]

75. Yin, J.; Li, Q.; Sun, Q. Antibiotic consumption in Shandong Province, China: An analysis of provincial pharmaceutical centralized bidding procurement data at public healthcare institutions, 2012-2016. J. Antimicrob. Chemother. 2018, 73, 814-820. [CrossRef]

76. World Health Organization. Global Antimicrobial Resistance and Use Surveillance System (GLASS) Report: Early Implementation 2020; World Health Organization: Geneva, Switzerland, 2020. 